\title{
Uma Controvérsia Luso-Britânica: o Caso do Cacau de São Tomé*
}

Rui Miguel Martins Mateus

(CETAPS)

\section{Introdução}

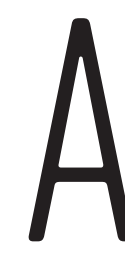

tensão existente nas relações luso-britânicas no final do século XIX e início do século XX deveu-se, em grande parte, ao Ultimatum de 1890. A frágil relação entre Portugal e a Grã-Bretanha agravou-se com uma polémica que levou os chocolateiros ingleses a boicotarem a importação de cacau proveniente de São Tomé e Príncipe, o que, por sua vez, gerou um escândalo na imprensa nacional e internacional.

Partindo de uma análise de várias notícias do jornal O Século, publicadas entre 1907 e 1913, pretende-se reflectir sobre o modo como a imprensa portuguesa percepcionou este boicote. Tendo em conta essa análise, tentar-se-á identificar a imagem que os portugueses tinham dos britânicos num contexto de tão grande tensão no respeitante à aliança anglo-lusa.

$\mathrm{O}$ presente artigo divide-se em quatro partes fundamentais que visam contribuir para uma melhor compreensão dos ecos do escândalo na imprensa e da forma como o boicote influenciou negativamente

* $\quad$ Este artigo resulta de um trabalho de investigação realizado no âmbito do seminário de Mestrado "Cruzamentos Culturais Luso-Britânicos", leccionado pela Prof. ${ }^{a}$ Doutora Gabriela Gândara Terenas. 
a relação entre Portugal e a Grã-Bretanha. A primeira parte trata-se de uma secção teórica sobre imagem e propaganda, ferramentas essenciais para a análise da imprensa. Neste ponto, tentar-se-á perceber como as representações do Eu e do Outro funcionam em textos jornalísticos, bem como a importância da propaganda na imprensa e o modo como influencia a opinião pública.

$\mathrm{Na}$ segunda, pretende-se apresentar uma contextualização de cariz histórico relativa à situação dos serviçais nas ilhas de São Tomé e Príncipe. Trata-se de um breve estudo sobre as mudanças aí ocorridas, desde a abolição da escravatura, na segunda metade do século XIX, até cerca de 1916, quando o conflito se atenuou. Para um melhor entendimento da situação dos serviçais, os relatórios dos britânicos, decorrentes das visitas às colónias portuguesas, afigurar-se-ão de grande relevância. O objectivo último reside em determinar se havia realmente escravatura (ou não) na colónia produtora de cacau.

A terceira parte tratará de identificar os agentes que estiveram por detrás do escândalo, nomeadamente William Cadbury, ${ }_{1}^{1}$ o empresário britânico que iniciou o boicote. Para melhor entender as razões deste boicote, tornar-se-á necessário ter em conta a natureza dos Quaker, grupo em que os próprios chocolateiros se inseriam, bem como as Sociedades Humanitárias, das quais os Quaker faziam parte. Aqui será também incluída a visão dos chocolateiros sobre o assunto.

A última parte incidirá na análise das notícias dedicadas à polémica, com vista, por um lado, a tentar perceber a imagem que o público leitor poderia construir dos britânicos que levavam a cabo estas acções contra Portugal, e, por outro, o modo como as notícias podiam influenciar a opinião pública. Aqui tentar-se-á responder às seguintes questões: Que tipo de propaganda era feita? $\mathrm{O}$ que a imprensa portuguesa publicava (em particular O Século) assemelhava-se (ou não) ao que os jornais ingleses noticiavam? ${ }^{2}$

1. Neto de John Cadbury (fundador da firma Cadbury), William Cadbury (1867-1957) foi o representante da família e do negócio na campanha britânica contra o cacau de São Tomé.

2. As fontes para realizar essa comparação restringem-se aos relatórios que os britânicos publicavam acerca do que se passava em São Tomé e ao que a imprensa portuguesa retirava da inglesa. 
Finalmente, procurar-se-á também esclarecer se as razões por detrás do boicote à importação de cacau de São Tomé, bem como de toda a campanha, eram realmente perceptíveis à primeira vista ou se existiam outras causas, alheias aos portugueses, que fossem mais verdadeiras, embora, de alguma forma, favoráveis aos interesses britânicos e não facilmente inteligíveis.

\section{Imagem e Propaganda}

O encontro do Eu com o Outro é crucial na formação de uma imagem. A partir deste encontro, torna-se possível atribuir características ao Eu, que percepciona o Outro. Tal constitui um dos elementos básicos da imagologia. A forma como as imagens variam relaciona-se com a perspectiva daquele que as constrói, originando, portanto, vários tipos de imagem. A auto-imagem, a forma como um indivíduo se vê a si mesmo, pode resultar de dois cenários possíveis: a auto-avaliação do próprio indivíduo, conducente à construção consciente ou inconsciente da auto-imagem; ou o encontro com o Outro, em que o sujeito, ao construir uma imagem desse Outro, cria automaticamente uma imagem de si próprio, resultante da comparação entre si e o Outro indivíduo/realidade. Além disso, o encontro entre dois indivíduos constitui um momento de formação da identidade e da alteridade.

A imagem contribui para a formação de estereótipos. Geralmente, o estereótipo é uma imagem fixa, com uma conotação negativa e associada, não raro, a preconceitos, distorcendo a realidade. No entanto, enquanto o estereótipo tende a manter-se ao longo do tempo, as imagens podem alterar-se. Segundo Manfred Beller e Joep Leerssen, em Imagology. The Cultural Construction and Literary Representation of National Characters. A Critical Survey (2007), as mudanças operadas, ao longo do tempo, nas imagens de indivíduos ou grupos, têm um resultado cumulativo, ou seja, ao invés de anularem um traço antigo, acrescentam-no ao catálogo de imagens existentes, podendo resultar em imagens contraditórias. (343) 
Deve também ter-se em conta o contexto sociocultural da época em que determinado texto surge. Por exemplo, o caso do cacau de São Tomé e Príncipe, objecto de estudo do presente artigo, produziu na imprensa portuguesa uma série de imagens relativas à Grã-Bretanha, que, em outro contexto, não teriam sentido.

A imagem é também uma linguagem, pois tem um vocabulário próprio, associável à representação. A representação do Outro pode revelar determinadas atitudes ou sentimentos. A "fobia" reporta-se a uma atitude negativa em relação ao grupo e ao indivíduo representado, remetendo para uma certa inferiorização do Outro relativamente ao Eu. Por seu turno, a "filia" revela um interesse e uma atitude positiva para com o representado. Segundo Álvaro Manuel Machado e Daniel-Henri Pageaux, em Da Literatura Comparada à Teoria da Literatura (2001) está-se perante um sentimento de "filia" quando "a realidade cultural estrangeira é tida por positiva e [se situa] no interior de uma cultura igualmente considerada de maneira positiva". (61) Por fim, deve considerar-se a "mania", um sentimento exacerbado de admiração pela cultura do Outro. Este sentimento inferioriza a cultura do Eu e pode, até, ridicularizá-la.

Ao levar a cabo um estudo que implique um cruzamento entre duas culturas diferentes, como no caso em apreço, torna-se importante perceber não só como funciona a imagologia, mas também a propaganda, já que as fontes primárias são textos da imprensa de cariz político. Afigura-se, assim, relevante, perceber como a propaganda contribui para acentuar (ou não) determinada imagem no seio da opinião pública.

A propaganda apela às emoções dos indivíduos, de modo a obter a sua aprovação. Cria-se, assim, o que Douglas Walton, em Media Argumentation: Dialectic, Persuasion and Rhetoric (2007), denominou "mob mentality", resultante desse apelo, como se fosse a própria multidão a falar. (100) Enquanto forma de argumentação, a propaganda baseia-se, em grande medida, na invocação das emoções, contribuindo para a irracionalidade do próprio argumento. Deve referir-se que, de acordo com Walton, mesmo que se trate de um apelo emocional, pode não ser falacioso: "some kinds of ad populum arguments (...) can sometimes be reasonable". (102) 
Embora o termo propaganda tenha geralmente uma conotação negativa, segundo Walton, é uma tarefa difícil defini-lo devido, talvez, aos vários usos que a palavra teve ao longo do tempo. De facto, se se observar a origem do vocábulo, percebe-se que este não tinha a conotação negativa dos dias de hoje. Ao tempo da Contra-Reforma, por exemplo, para os católicos o termo não era negativo, mas para os protestantes tinha essa conotação. (293) O uso da palavra na guerra ou na política ajudou a acentuar a negatividade com que o termo é hoje percepcionado pela opinião pública.

Walton questiona-se, assim, sobre se o termo propaganda deve ser associado exclusivamente a aspectos negativos (ou não), propondo as categorias utilizadas por Randal Marlin em Propaganda and the Ethics of Persuasion (2002) para definir propaganda: positiva, negativa ou neutra.

Assim, a propaganda de tipo positivo verifica-se apenas em duas ocasiões: para transmitir informação em tempos de guerra e para difundir a cidadania em determinado local, através da promoção do conceito de comunidade. A propaganda negativa prende-se com a promoção de interesses e a manipulação psicológica para persuadir o público a aderir a determinada causa ou crença. As razões pelas quais se trata de um tipo negativo de propaganda residem na constante fuga à verdade ou na tentativa de controlar o comportamento das pessoas. Quanto às definições de propaganda de tipo neutral, deve referir-se a divulgação de ideias para influenciar a opinião pública; ou a propaganda apenas como meio divulgação de informação, seja ela verdadeira ou falsa. (95)

Todavia, estas categorias, no seu conjunto, contribuem para uma visão tendencialmente negativa do termo propaganda, uma vez que as definições negativas superam a soma das visões neutrais e positivas.

A propaganda pode ainda ser vista como um diálogo, existindo vários tipos de diálogo, cada um com um objectivo específico. Por exemplo, o diálogo erístico utiliza argumentos não necessariamente válidos para tentar vencer uma discussão, tentando, por exemplo, humilhar o Outro. Este aspecto relaciona-se bastante com a imagologia, pois parece estar-se perante uma situação propícia à existência 
de sentimentos de "fobia". Outro tipo de diálogo é o persuasivo, em que uma das partes vai tentar defender-se. Este aspecto encontra-se presente na defesa de Portugal no jornal O Século contra as acusações britânicas.

A ligação da propaganda com a imprensa é bastante íntima porque esta acaba por a utilizar como um veículo de imagens para tentar influenciar a opinião pública. O jornal O Século constitui um dos veículos de propaganda a favor da causa de Portugal no caso do cacau de São Tomé, tratando-se, portanto, de propaganda lusófila. Em sua defesa, os jornalistas portugueses acabam por atacar a Grã-Bretanha, difundindo uma imagem negativa dos ingleses, ou seja, de anglofobia.

\section{De Angola a São Tomé: Rumo à Liberdade ou à Escravatura?}

Quando o chocolateiro inglês William Cadbury se apercebeu de que parte do cacau que comprava poderia ser fruto de trabalho escravo, levou a cabo uma investigação para determinar a veracidade dos factos. Com a averiguação veio também uma campanha contra Portugal que se traduziu num boicote à importação de cacau de São Tomé. Neste contexto, torna-se necessário analisar o tipo de trabalho executado nas roças para se tentar compreender as acções dos britânicos nesta campanha.

Determinar a existência (ou não) de mão-de-obra escrava nas ilhas de São Tomé e Príncipe afigurava-se uma tarefa complexa. Os diversos relatos sobre o que se passava na colónia não facilitavam o entendimento claro da situação, pois muitos deles eram de tal forma contraditórios que se tornava quase impossível determinar a sua veracidade.

Ao contrário de outras colónias portuguesas, as ilhas de São Tomé e Príncipe, apesar de também possuírem uma terra bastante fértil, tinham falta de mão-de-obra. Assim, sendo a população escassa, tornava-se necessário importá-la de outras colónias.

O trabalho escravo nas ilhas de São Tomé era uma prática comum desde o início da administração portuguesa. No entanto, durante o período em que o Brasil se tornou um grande produtor de 
cana-de-açúcar, a exploração de cacau em São Tomé estagnou. Porém, a introdução das culturas do café e do cacau, no início do século XIX, fez a colónia ressurgir. Desta forma, a necessidade de importação de escravos tornou-se novamente uma questão importante para a sobrevivência da agricultura das ilhas.

A abolição da escravatura nos domínios portugueses colocou novamente em perigo o desenvolvimento da colónia. A lei de 25 de Fevereiro de 1869 determinava que todos os escravos passavam a ter o estatuto de libertos. No decreto lia-se o seguinte: "em 25 de Fevereiro de 1869 foi abolido o estado de escravidão, passando todos os escravos ao estado de libertos." (Almada, Apontamentos 41) Estes passaram a ser pagos e tratados como trabalhadores, mas os contratos eram-lhes impostos.

Segundo Lopo Vaz de Sampaio e Mello, ${ }^{3}$ em Política Indígena: Questões Coloniais (1910), a abolição da escravatura tinha precedentes no decreto de 29 de Abril de 1858, "que fixava um periodo de 20 annos para a emancipação progressiva dos escravos que, se ainda alguns houvesse em 1878, passariam á condição transitoria de libertos." (305)

Na prática, os contratos forçados constituíam uma forma de os produtores de cacau manterem os escravos, sob o pretexto de que eram serviçais contratados. Deste modo, as ilhas de São Tomé e Príncipe conservavam uma forma de escravatura que oficialmente não o era. Os serviçais, como eram designados estes "escravos", eram forçados a trabalhar, mas a troco de um salário. Por seu turno, os governadores emitiam decretos que impunham o trabalho como forma de civilizar África. O historiador James Duffy referiu-se a esta situação como "improper labour practises in Angola and São Tomé", denominando-a "neo-slave-trade" (Portugal 134) e afirmando que os roceiros continuavam a tratar os libertos como escravos.

Face ao evidente descontentamento dos trabalhadores, o Governador de São Tomé, Gregório Ribeiro, ${ }^{4}$ aboliu o trabalho forçado

3. Lopo Vaz de Sampaio e Mello (1848-1892) foi Ministro da Justiça entre 1883 e 1885 e, novamente, em 1890

4. Gregório José Ribeiro foi Governador de São Tomé e Príncipe entre 1873 e 1876. 
em 1875. Esta medida teve um impacte negativo na economia da colónia, estagnando, mais uma vez, a produção. Segundo Sampaio e Mello, várias tentativas foram levadas a cabo com o intuito de utilizar a mão-de-obra local, mas, em vão, pois os nativos recusavam-se a trabalhar. O mesmo dizia William Cadbury no seu relatório, elaborado após uma visita a São Tomé. Entre os nativos havia o seguinte ditado: "o filho de S. Thomé não trabalha." (17)

Assim, segundo Sampaio e Mello, grande parte da mão-de-obra de São Tomé vinha de Angola e outra de Moçambique, cujos nativos eram bastante mais laboriosos do que os angolanos. $(1910,307)$ Alguns dos trabalhadores eram oriundos de Cabo Verde, da Guiné e de Macau. Os serviçais de Cabo Verde faziam contratos de dois anos, sendo depois repatriados. Os restantes assinavam contratos de cinco anos que podiam ser renovados. O resultado dos serviçais provenientes de Macau foi medíocre, embora nem o autor do artigo, nem o jornal O Século, que faz referência à questão, explicam porquê.

A não repatriação (sobretudo dos angolanos) constituía um dos problemas da administração colonial de São Tomé, sendo apontado como algo negativo nos relatórios dos britânicos que visitaram a ilha. O Cônsul britânico em Luanda, Arthur Nightingale, referiu, no seu relatório de 1906, as condições satisfatórias em que os serviçais eram tratados, mas a falta de repatriação preocupava-o:

The only black spot, and it is a big black spot, on the whole system is the non-repatriation of the Angola labourer. That is one great evil, and it behoves the Portuguese Government to put an end to the present mode of recruiting labourers in Angola as soon as possible. (Santos 2004, 981)

Tentando expor as causas da campanha contra Portugal, Sampaio e Mello apontava a prosperidade da colónia e o crescimento da economia portuguesa, no seio da Europa, resultante da produção de cacau. Estes factores, positivos para Portugal, eram vistos de forma negativa pelos britânicos, os quais, segundo Sampaio e Mello, invejavam o sucesso económico do seu pequeno aliado. (310) Em tom de contra-ataque, o mesmo autor apontava para a situação das minas de 
ouro do Transval e para a forma como os trabalhadores eram aí tratados, tentando contrapor a sua situação à dos serviçais de São Tomé, que, segundo os relatórios de alguns visitantes, viviam e trabalhavam em condições mais do que satisfatórias.

As ilhas de São Tomé e Príncipe foram visitadas por pessoas de diversas partes da Europa, incluindo a França, a Alemanha e a GrãBretanha. $\mathrm{O}$ elogio à qualidade de vida e às condições de trabalho dos serviçais era inegável. Estes eram pagos, alimentados e alojados, e quando o contrato terminava podiam ser repatriados. As crianças com menos de quinze anos não trabalhavam. O próprio William Cadbury escreveu que as condições de alojamento dos serviçais eram semelhantes às dos trabalhadores das roças das Antilhas, onde o horário de trabalho era de cerca de nove horas diárias, à excepção dos Domingos, sendo, não raro, realizado num ambiente bastante favorável. Os salários eram muito baixos, mas, tendo em conta a gratuitidade do alojamento, da alimentação e do vestuário, a quantia era considerada razoável.

Uma lei emitida em Janeiro de 1903 previa que dois quintos do salário do serviçal fossem direccionados para o Fundo de Repatriação para assegurar o regresso. Ao abrigo desta lei encontravam-se os serviçais cujos contratos haviam sido assinados depois de a lei ter entrado em vigor. Os que tinham contratos assinados antes desse período só foram abrangidos pela mesma lei em 1913.

Contudo, deve referir-se que uma grande parte dos serviçais não era de facto repatriada. Segundo várias fontes, muitos desejavam ficar em São Tomé e renovar os contratos por mais cinco anos. Outras fontes relatavam a impossibilidade dos serviçais regressarem, sobretudo os de origem angolana, devido à enorme distância que os separava da terra natal. Por outro lado, os problemas que afectavam os nativos antes de seguirem para São Tomé podiam constituir uma das razões pelas quais não queriam ser repatriados, desejando, antes, renovar os contratos.

Se o recrutamento de serviçais no interior de Angola era feito de forma desumana, torna-se, no entanto, necessário sublinhar o contraste entre esta situação e o modo de vida nas roças. A este propósito, José de 
Almada escreveu o seguinte: "recruitment in the Portuguese Colonies is said to be a farce, because the blacks are dragged by their chiefs to sign the contracts." (Comparative 16) Todavia, Almada considerava este problema comum a todas as colónias europeias em África. Na verdade, a ida para São Tomé era uma bênção para os angolanos, autênticos objectos de escravatura por parte dos vendedores. Nestas circunstâncias era expectável que os serviçais não quisessem regressar, pois corriam o risco de receber novamente o mesmo tipo de tratamento.

Até 1911, o repatriamento dos serviçais era praticamente inexistente. Depois, o processo continuou a ser longo e difícil, só se podendo fazer um balanço positivo desta questão, a partir de 1916, como se pode verificar no Anexo I. ${ }^{5}$

Em A Modern Slavery (obra publicada pela primeira vez em 1906), Henry Nevinson ${ }^{6}$ atacou Portugal no respeitante ao trabalho contratado em São Tomé. Para o autor, os serviçais eram escravos, as condições vividas nas roças desumanas e a elevada taxa de mortalidade justificava a constante procura de mão-de-obra. Quanto ao destino de parte do salário para o Fundo de Repatriação, Nevinson escreveu o seguinte: "in the case of the slaves from Angola this is never done, and it is much to the credit of the Portuguese that, as there is no repatriation, they have dropped the institution of a Repatriation Fund." (112)

A descrição apresentada por Nevinson, no capítulo dez da obra, baseou-se sobretudo em relatos fornecidos por terceiros, pois nele o autor sustentou ocorrências por si não presenciadas, facto que poderá contribuir para pôr em causa a veracidade das suas afirmações. Nevinson terminou o referido capítulo, afirmando que a palavra escravatura fora substituída por trabalho contratado ou trabalho forçado, uma prática bastante lucrativa para Portugal. (120)

Aparentemente, só com a ameaça de um boicote à importação do cacau português se tomaram medidas para tentar melhorar as condições dos trabalhadores das roças. Embora a campanha tenha

5. Cf. Duffy $1967,228-29$

6. Henry Nevinson (1856-1941) foi um jornalista britânico e correspondente durante a Segunda Guerra Anglo-Bóere. Um dos seus principais trabalhos incluiu a investigação para a Harper's Monthly sobre o trabalho escravo em Angola. 
precedentes em 1865, apenas no início da primeira década do século XX começou a ganhar forma, atingindo o seu auge em 1906, quando foi proibida, por quatro anos, a importação de cacau de São Tomé.

Perante as diversas opiniões acerca do assunto, torna-se difícil determinar se existia realmente escravatura ou não. Alguns dos relatórios afiguram-se algo duvidosos, uma vez que houve uma tentativa, tanto por parte do Foreign Office como do Governo português, de abafar a campanha. Segundo o Foreign Office, os britânicos não deveriam envolver-se nos assuntos internos portugueses. No entanto, pode presumir-se que o desejo dos ingleses em não transformar a campanha num escândalo se prendia com os interesses na mão-de-obra originária de Moçambique nas minas de ouro do Transval. ${ }^{7}$

Apesar dos relatos duvidosos, mesmo no século XX, a existência de escravatura nas ilhas de São Tomé e Príncipe afigura-se bastante credível. No entanto, pode afirmar-se que as condições de vida dos serviçais nas roças progrediram muito em relação ao período anterior à abolição da escravatura e foram melhorando mais ao longo do tempo. É claro que o bom tratamento dos serviçais por parte dos roceiros podia simplesmente advir do excesso de procura e do elevado preço de compra, fazendo do serviçal um bem precioso e indispensável. Os baixos salários e a impossibilidade de muitos não conseguirem regressar à terra de origem constituem factores que contribuem para fortalecer a tese da existência de trabalho escravo na colónia portuguesa.

Deste modo, pode concluir-se que existe uma ligação directa entre as condições em que os serviçais eram recrutados em Angola (escravos recrutados à força) e a sua permanência em São Tomé, onde recebiam um tratamento que se podia considerar na fronteira entre a escravatura e o trabalho contratado.

Para se perceber melhor as razões da campanha britânica, torna-se necessário saber quem eram os chocolateiros Quaker que faziam parte de sociedades humanitárias ligadas à abolição da escravatura. A informação acerca dos Quaker e das sociedades humanitárias ajudarão a compreender os motivos da campanha.

7. Cf. Duffy 1967,182 . 


\section{Uma Campanha Humanitária?}

Antes de entrar em pormenores sobre forma a como a empresa Cadbury conduziu a campanha contra Portugal, no respeitante ao cacau de São Tomé, torna-se importante perceber as origens da família e o seu interesse na possível existência de trabalho escravo nas colónias portuguesas.

A família Cadbury fazia parte dos Quaker, grupo puritano surgido na Grã-Bretanha, em meados do século XVII. De cariz eminentemente religioso, os Quaker, privilegiavam, entre outros aspectos, a ligação directa com Deus, baseada na experiência que o seu fundador, George Fox, ${ }^{8}$ declarara ter tido. No entanto, os Quaker tornaram-se mais conhecidos, nomeadamente no século XIX, por outras razões, tal como Pink Dandelion explica: "Quaker opposition to war and work for peace, as well as (...) opposition to slavery is perhaps what Quakers are best known for today." $(2008,1)$ Assim, o interesse dos Quaker na abolição da escravatura levou à formação de várias sociedades anti-esclavagistas no século XIX.

A Aborigenes' Protection Society (APS), fundada em 1937 por Thomas Hodgkin, dedicou parte da sua vida à Medicina. Hodgkin representou a APS na "World Anti-Slavery Convention", que teve lugar em Londres, em 1840. De acordo com Nworah, esta sociedade humanitária tinha como principais objectivos a preservação dos direitos das tribos indígenas e a promoção da sua civilização e religião. (1971, 79) A "Anti-Slavery Convention" constituiu uma tentativa de promover a campanha de libertação de escravos fora do Império britânico, onde já tinha sido abolida a escravatura em 1833. Segundo Deborah Cadbury, o objectivo dos Quaker era o seguinte:

8. George Fox (1624-1691) fundou o grupo por volta de 1652 com o apoio de vários pregadores como James Nayler e Edward Burrough. 
They wanted not only to stop the slave trade but also to free all existing slaves. Their work culminated in the Slavery Abolition Act of 1833, which paved the way for the gradual emancipation of all slaves across the British Empire. The British and Foreign Anti-Slavery Society then took their campaign to other countries. $(2010,197)$

Enquanto representante da APS, a reputação de Hodgkin era bastante boa, sendo considerado um defensor das leis de igualdade entre brancos e negros. No entanto, Henry Fox Bourne (1837-1909), secretário desta sociedade humanitária, adquiriu grande visibilidade na questão da escravatura. O seu pai, Charles James Fox, tinha sido enviado para a Jamaica para proceder à libertação dos negros.

A APS granjeou grande reputação pelas suas campanhas contra a escravatura na África Ocidental, especialmente na última década de Oitocentos. Um dos seus maiores projectos dizia respeito à escravatura de menores, praticada na Costa do Ouro. ${ }^{9}$ Por este motivo, a Sociedade contribuiu para o fortalecimento das leis contra o trabalho escravo. Uma das suas crenças era a de que a violência não ajudava o processo civilizacional, portanto, defendia que "the hunting down of such people, with destruction of their villages and slaughter of large numbers could have no civilizing effect on the survivors." (Nworah 1971, 84) O envolvimento da APS estendeu-se a causas humanitárias em diversas áreas de África e fora de colónias britânicas, nomeadamente no Congo, em Angola e nas Ilhas de São Tomé e Príncipe.

Durante a primeira década do século XX, a Sociedade passou por um período de declínio em que os seus esforços, bem como os da Anti-Slavery Society, outra sociedade humanitária que tinha sido fundada em 1823, não produziam os efeitos esperados. Por esse motivo, e com a morte de Fox, em 1909, as sociedades fundiram-se, em 24 de Junho desse ano, formando a Anti-Slavery and Aborigines' Protection Society. As sociedades humanitárias eram apoiadas pelas famílias Quaker, como os Cadbury, donos de uma das maiores empresas britânicas de chocolate, no início do século XX. Fazendo os Cadbury parte

9. Actual Gana. 
das sociedades humanitárias, um escândalo como o do cacau de São Tomé constituía uma afronta à reputação da família e do negócio.

Segundo Deborah Cadbury, a primeira vez que os Cadbury ouviram acerca do alegado comércio de escravos nas colónias portuguesas foi em 1900. (2010, 194) Seguiram-se reuniões em Lisboa, para tentar esclarecer o assunto, tendo William Cadbury sido informado pelo então Ministro das Colónias, Manuel Gorjão, de que havia um problema que seria solucionado pelo decreto de 1903, já referido.

Cadbury acabou por conseguir o apoio dos Quaker, em Inglaterra, bem como de outras firmas produtoras de chocolate, como a Rowntree, a Fry e a alemã Stollwerck. Com este apoio começaram os debates acerca das medidas a tomar para resolver o problema. Antes de se optar por um boicote à importação do cacau de São Tomé foram tomadas diligências para investigar o que realmente se passava na África portuguesa.

Ao mesmo tempo que decorria esta investigação, Nevinson levava a cabo a sua expedição por Angola, onde descobriu, segundo o seu relatório, que " the path is strewn with dead men's bones (...) the skeletons of slaves who were unable to keep up with the march and so were murdered or left to die." $(2010,200)$ Nevinson apercebeu-se de que havia comércio escravo em Angola e, em 1905, publicou um relatório na Haper's Monthly Magazine, precisamente na altura em que as ilhas portuguesas atingiram, ainda que por pouco tempo, o primeiro lugar como produtoras de cacau. (203)

O relatório de Nevinson constituiu o impulso para a investigação dos chocolateiros, que nomearam Joseph Burtt ${ }^{10}$ para visitar a colónia de São Tomé e investigar o problema. Quando Burtt confirmou a veracidade do que Nevinson publicara, os chocolateiros reuniram-se imediatamente com o Foreign Office para procurar uma solução para o caso. Todavia, o Foreign Office pediu a máxima discrição até que houvesse oportunidade de esclarecer a questão com o Governo português. Este impasse prendia-se com a tentativa do Governo britânico estabelecer um acordo com Portugal relativo ao recrutamento de trabalhadores em Moçambique para as minas de ouro do Transval.

10. Quaker e botânico, Joseph Burtt (1870-1940) dedicou-se sobretudo à flora africana. 
Deste modo, os Quaker sentiam pressão de ambas as partes. De um lado, estavam os valores da doutrina Quaker e das sociedades humanitárias. Do outro, encontrava-se o Foreign Office a tentar abafar a campanha para não causar um escândalo que afectasse as relações luso-britânicas. A passividade dos chocolateiros começou a pôr em causa a sua honestidade e a dos restantes Quaker junto da imprensa. A ideia de que o chocolate produzido pela fábrica Cabdury era fruto de trabalho escravo começou a causar uma onda de revolta na opinião pública britânica. O prolongamento da campanha contribuiu para que esta ideia se sedimentasse, acabando os chocolateiros por boicotar a importação de cacau de São Tomé, em 1909.

Toda a campanha contra Portugal causou uma onda de propaganda negativa na imprensa portuguesa, que acusava a Grã-Bretanha de tentar prejudicar a economia portuguesa, sustentada, em grande parte, pelo sucesso económico de São Tomé.

\section{Ecos de uma Polémica em 0 Século}

A campanha levada a cabo pelos chocolateiros tornou-se um escândalo público na imprensa portuguesa, na britânica, na francesa e na de vários outros países da Europa, estendendo-se também à América. Em Portugal, o jornal O Século deu conta do escândalo. Neste periódico pode analisar-se a forma como os britânicos, sobretudo os que chefiavam a campanha, eram vistos pela imprensa. Ao mesmo tempo, Portugal fez a sua própria (contra-)propaganda, tentando combater a Grã-Bretanha. Fundado por Sebastião de Magalhães Lima, ${ }^{11}$ em 1881, O Século foi um jornal de grande circulação em Portugal que se destacou, desde o início, pelo apoio ao republicanismo. O último número foi publicado em 1977.

Este ponto visa analisar as notícias sobre a campanha publicadas em O Século, entre 1907 e 1913, o período mais aceso de toda a

11. Político e jornalista, Sebastião de Magalhães Lima (1850-1928) foi republicano e Grão-mestre da Maçonaria. 
campanha, que só terminou, como se viu, em 1916. Assim, logo no dia 1 de Fevereiro de 1907, O Século fez uma publicação em defesa de Portugal face à campanha. Através de uma notícia publicada em Tour $d u$ Monde, ${ }^{12} \mathrm{O}$ Século fez a sua propaganda relativa às condições de trabalho dos indígenas, em São Tomé, referindo as ilustrações publicadas no periódico francês, onde se podia ver o Conde de Vale-Flôr ${ }^{13}$ "acariciando filhos dos serviçais." (O Século, 1 Fevereiro 1907, 2) Na mesma notícia atacava-se os Estados Unidos e a Grã-Bretanha, acusando-se os primeiros de tentarem combater a concorrência através de uma guerra económica. O jornal Tour du Monde acrescentava que não havia qualquer fundo de verdade nas acusações.

Cerca de um mês depois, a Alemanha entrou em defesa de Portugal, com um artigo publicado no Gordinn,${ }^{14}$ onde se consideravam "calumniosas as afirmações interessadas dos inglezes ao acusarem Portugal de permitir a escravatura em S. Thomé." (2 Março 1907, 2) A participação da Alemanha no conflito (do lado de Portugal) pode justificar-se pela rivalidade económica com a Grã-Bretanha. Ao tomar o partido de Portugal na campanha, os chocolateiros alemães tentavam desacreditar a Grã-Bretanha, afectando possivelmente o comércio do chocolate britânico, que já fora prejudicado com o escândalo causado pela campanha. No entanto, a Stollwerck, empresa alemã, tinha-se aliado a Cadbury, contrariando, de certa forma, a tomada de posição dos restantes chocolateiros alemães.

O Século descrevia a campanha como "implacável" e "injustíssima". Num dos artigos afirmava-se que o objectivo era claro: "tenta-se desprestigial-o [o domínio colonial português] aos olhos das nações cultas." (11 Março 1907, 5) Portugal colocava-se ao lado das outras nações europeias com possessões em África, acusando-as de tratar os indígenas com um grau de humanidade muito abaixo do português. As acusações eram especialmente dirigidas ao Congo belga que, segundo $O$ Século, tentara arruinar a economia portuguesa em Angola.

12. Jornal francês criado por Édouard Charton, em 1857.

13. Produtor de cacau em São Tomé e proprietário da roça Boa Vista.

14. Jornal e órgão oficioso dos chocolateiros alemães. 
$\mathrm{Na}$ propaganda deste periódico, as atenções foram desviadas para a situação de outras nações. Desta forma, Portugal conseguiu demonstrar que as acusações não eram verdadeiras, uma vez que existiam países que tratavam os seus indígenas de forma bastante pior. Ao fazer estas acusações, Portugal provava ainda que a campanha dos chocolateiros não era levada a cabo por motivos humanitários, ao mesmo tempo que tentava afastar as atenções do assunto. O Século elogiava e agradecia, ainda, às nações europeias, como a França, que haviam defendido Portugal na campanha.

No entanto, também a Suíça, produtora de chocolate, partilhou das críticas contra os portugueses, acusando-os de práticas esclavagistas. O Século explicava a reacção da Suíça como uma tentativa de invalidar a concorrência alemã, obtida através do cacau de São Tomé. O Século via todas estas acusações como atitudes de inveja por parte dos produtores de chocolate, porque o cacau de São Tomé era o terceiro mais exportado no mundo, em 1907. (Cadbury 1910, 24) Nos artigos do jornal encontra-se uma larga insistência na falsidade das acusações: "nós [portugueses], cá, bem sabemos que taes asserções são inteiramente falsas." (11 Março 1907, 5)

$\mathrm{O}$ artigo de 11 de Março referia-se à campanha como uma "guerra mercantil", disfarçada de campanha humanitária. O contra-ataque português ia na direcção das atrocidades cometidas pelos Quaker contra os "povos amarellos" (japoneses e chineses). Com ironia, O Século referia-se ao interesse destes (pseudo-)humanitários relativamente às condições de vida dos indígenas das colónias portuguesas: as intenções dos britânicos, na campanha humanitária, eram, no mínimo, estranhas, uma vez que a aquela não se estendia a outros territórios (como o já referido Congo belga), onde os portugueses haviam defendido a existência de atrocidades bem piores.

O mesmo artigo sublinhava a celebridade de Nevinson na campanha e na publicação de A Modern Slavery, onde afirmava haver escravatura na África Ocidental portuguesa. O Século acusava Nevinson de não ter provas acerca do que escrevia, afirmando que o seu nome era desconhecido entre os que realmente conheciam África. No entanto, a notícia não apresentava nada que comprovasse 
estas afirmações. Um outro artigo do mesmo dia mencionava uma publicação no jornal Daily Chronicle, por Clapham, que O Século assumiu imediatamente tratar-se de Nevinson, em que se descrevia a "forma horrorosa como é exercido o commercio de escravos." (11 Março 1907, 6)

Em 1908, William Cadbury tornou-se o representante dos chocolateiros britânicos e alemães. Em consequência, O Século acusou-o de ter redigido um relatório falso acerca do trabalho indígena em São Tomé. Contrariamente, os franceses continuavam a defender Portugal contra as acusações e a disfarçada campanha dos britânicos. Na notícia abaixo citada, O Século apontava mais uma razão para a existência da campanha contra Portugal:

A actual campanha dos chocolateiros ingleses é auxiliada pelos proprietarios das minas do Rand, cujo intuito é o de exercerem pressão sobre Portugal para evitar que esse paiz reclame contra a escravidão soffrida nas mesmas minas por milhares de indigenas saidos de Moçambique. (30 Setembro 1908, 1)

A defesa de Portugal por parte de O Século, nesta altura, foi bastante intensa. As afirmações dos britânicos, que O Século classificou como caluniosas e insidiosas, mantiveram-se, segundo o periódico, apesar das refutações dos portugueses. Nesta altura, The Standard e The Times eram os jornais britânicos com maior envolvimento na campanha. A acusação de O Século centrava-se sobretudo na forma de recrutamento de trabalhadores indígenas para as minas do Rand, pelo que, uma vez que o elogio dos ingleses a Cadbury pelo seu humanitarismo e filantropia era tão grande, talvez o chocolateiro se devesse preocupar também com outras situações semelhantes.

A carta publicada por Nevinson em The Times, no dia 7 de Outubro de 1908, congratulava Cadbury pela sua iniciativa de visitar São Tomé, reforçando a existência de escravatura nas ilhas e em Angola. O Século anunciava também uma reunião das sociedades anti-esclavagistas em Londres para determinar acções futuras. O jornal português considerava tudo isto uma terrível forma de propaganda. 
Numa entrevista realizada a um colonizador francês não identificado, apresentava-se uma solução: "o modo mais fácil de acabar com essa propaganda seria (...) que o governo inglez declarasse officialmente que não podia intervir num assumpto (...) de um paiz independente." (8 Outubro 1908, 1) A estratégia de O Século era mostrar como havia alguém que defendia Portugal face às acusações dos ingleses. A forma como o jornal se referia à campanha - "a velha história da escravatura" - demonstrava o cansaço face à frequência com que Portugal havia sido acusado.

Jerónimo de Carvalho, então um aluno universitário, publicou um artigo intitulado "Desfazendo as calumnias", onde defendia Portugal como testemunha do que se passava em São Tomé. A sua posição, durante cerca de quatro anos, de Curador, na colónia de São Tomé, permitira-lhe ver de perto as condições em que os indígenas trabalhavam. Jerónimo de Carvalho revelava um particular desagrado face aos ingleses e às suas acusações, que descrevia como "baboseiras" e um "libelo afrontoso." (8 Outubro 1908, 1) Quanto aos interesses dos britânicos, afirmava que estes eram cobiçosos, veiculando, assim, uma imagem bastante negativa do povo de além-Mancha.

Todavia, ao criticar os britânicos, Jerónimo de Carvalho criava uma certa auto-imagem dos portugueses, identificando-os com verdade, honra e brio. A imagem dos portugueses era bastante positiva, pois o próprio Jerónimo de Carvalho afirmava sentir orgulho em sê-lo. Todavia, Carvalho descrevia o indígena como pouco civilizado, abaixo do europeu e, por isso, com necessidade de ser protegido, sendo esta a função do Curador. Descreveu, ainda, as condições de vida dos trabalhadores e o modo como aquelas seriam aprazíveis a muitos que não as tinham, recusando com grande veemência a existência de escravatura em São Tomé. Carvalho desdisse os britânicos, acusando-os de não terem provas concretas, uma vez que nunca haviam pisado o solo da ilha.

As notícias de O Século apresentavam não só fortes traços de anglofobia, mas também de lusofobia, evidenciando a tensão entre os dois países provocada pela campanha. 
O relatório de Joseph Burtt, publicado em Outubro de 1908, veio novamente confirmar a existência de escravatura. Qualquer dúvida até então existente ficava esclarecida com o relatório. O Século transcreveu alguns excertos do texto de Burtt, mostrando detalhadamente o que se passava em Angola e em São Tomé. Em tom de resposta às acusações dos portugueses acerca do trabalho indígena nas minas do Rand, The Times descrevia a experiência de Burtt, afirmando que as condições de trabalho constituíam "um perfeito contraste" com as de Angola. (11 Outubro 1908, 1)

O Século não deixou de referir a relutância do Foreign Office em publicar o Relatório, confirmando as suspeitas de que a campanha não era do agrado do Governo britânico, porque poderia, eventualmente, prejudicar as relações luso-britânicas noutros aspectos.

No dia 14 de Outubro de 1908, O Século citou um artigo do periódico britânico The Globe que acusava Portugal de não conseguir desenvolver as suas colónias devido à existência de escravatura. Acrescentava, ainda, que só a intervenção da Alemanha, da França ou de Inglaterra poderia resolver o caso. Até lá, quaisquer medidas tomadas pelo Governo português no respeitante à escravatura "serão letra morta." (14 Outubro 1908, 4)

A partir de finais de 1911 e durante o ano de 1912, a campanha começou a perder visibilidade junto da imprensa britânica. Os chocolateiros ingleses já tinham decretado o boicote ao cacau de São Tomé e Príncipe, em 1909, e o recrutamento de mão-de-obra proveniente de Angola encontrava-se suspenso. No entanto, o folheto de Jerónimo Paiva de Carvalho, publicado em 1912, fez ressurgir a questão. O jornal acusava Paiva de Carvalho de ter ressuscitado propositadamente a campanha, cuja notoriedade era visivelmente menor. Na verdade, as palavras do antigo Curador da ilha do Príncipe revelavam o desejo de reatear a campanha: "a verdade é como azeite vem ao de cima. E a verdade novamente desencadeará a tempestade." (7 Abril 1913, 1) O Século demonstrou a sua revolta e espanto pela atitude de Paiva de Carvalho, que tinha sido, até há poucos anos, um acérrimo defensor de Portugal na campanha, chegando a publicar no mesmo jornal artigos contra a acção da Grã-Bretanha. 
Para além das acusações ao português, também as denúncias sobre William Cadbury continuavam. Chamavam-lhe um "homem sem escrúpulos, a que todos os meios servem, desde que por eles atinja os seus fins." (7 Abril 1913, 1) O Século atacava imediatamente a boa imagem de Cadbury, que "muitos e importantes roceiros nossos por muito tempo consideraram como homem de boa fé." (5 Abril 1913, 1) O Século pretendia esclarecer os leitores e passar a imagem que julgavam verdadeira e, naturalmente, negativa.

A publicação do folheto de Paiva de Carvalho, intitulado Alma Negra, podia ser a confirmação, por parte dos portugueses, da existência de escravatura em São Tomé, algo que ajudaria largamente a campanha britânica. A revolta de O Século para com Paiva de Carvalho e Alfredo Henrique da Silva, ${ }^{15}$ que imprimira o panfleto, era tal, que condenavam o acto como criminoso, pelo que "não faltam leis nem tribuanes n'este paiz." (7 Abril 1913, 1) Henrique da Silva tentou desculpar-se junto de O Século, alegando que se tinha recusado a publicar o folheto sem alterações prévias que declarassem a sua desactualidade.

Freire de Andrade, Director Geral das Colónias, enviou para The Spectator uma carta acusando Paiva de Carvalho de duplicidade na campanha. No entanto, The Globe continuava a acreditar nos factos relatados por Paiva de Carvalho, explicando que a razão pela qual o português negara a autoria de Alma Negra se devera à pressão do Governo de Lisboa. Esta pressão tornava-se bastante credível para os britânicos devido à campanha que aqueles conduziam na altura, a propósito dos presos políticos em Portugal.

Em 1913, a campanha na imprensa portuguesa voltou-se mais para a questão do folheto Alma Negra, de certa forma negligenciando o problema directamente relacionado com as condições de trabalho na colónia de São Tomé e preferindo dirigir as suas acusações a Cadbury, a Paiva de Carvalho e a Alfredo Henrique da Silva.

No dia 9 de Abril de 1913, O Século publicou a defesa de Paiva de Carvalho. O antigo Curador explicou como fora incriminado pelos

15. Pastor Metodista e fundador da União Cristã da Mocidade (1984), Alfredo Henrique da Silva (18721950) foi autor de O Monstro da Escravatura (1913). 
chocolateiros britânicos que não o queriam no cargo. Foi declarado inocente, mas, após uma revolta de serviçais na ilha, em 1907, acabou por ser demitido. Quanto ao panfleto, tão mencionado em O Século com grande desagrado e repulsa, Paiva de Carvalho não admitiu ser o autor do mesmo, acusando o jornal de não ter provas da autoria de Alma Negra, "e, tendo-as, serão elas verdadeiras?" (9 Abril 1913, 1)

Seguiu-se uma publicação de uma carta, alegadamente de Paiva de Carvalho, que confirmava a existência da venda de um relatório a Cadbury por duzentas libras. Esse relatório dava conta das verdadeiras condições de trabalho dos indígenas em São Tomé, sendo fruto de cerca de cinco anos de contacto directo com as mesmas, o que, comparativamente às breves viagens dos investigadores britânicos (Cadbury e Burtt), seria decerto mais minucioso. Para além disso, O Século ainda obteve a confirmação de Alfredo Henrique da Silva de que o panfleto era efectivamente da autoria de Paiva de Carvalho.

Este artigo prova que a campanha levada a cabo pela imprensa portuguesa para tentar desmentir a imprensa britânica se desviou do objectivo principal, tornando-se uma campanha interna. Tratava-se de saber quem tomava o partido dos britânicos numa campanha (alegadamente) humanitária, bem como de quem tomava o partido dos portugueses, que acusavam os britânicos de interferir na gestão das colónias lusas para proveito próprio, negligenciando completamente as condições de trabalho em São Tomé e Príncipe. Deve sublinhar-se que o folheto (se realmente da autoria de Paiva de Carvalho) podia não corresponder à verdade, uma vez que fora publicado em 1912 com base em informação anterior a 1907, quando Paiva de Carvalho fora demitido do cargo de Curador. Ainda se pode questionar se o panfleto não terá sido uma manobra estratégica, por parte dos chocolateiros ingleses, para atrair mais seguidores para a sua causa, confundindo, assim, a imprensa portuguesa. De facto, um documento da natureza de Alma Negra afigurava-se bastante prejudicial à credibilidade de Portugal e da sua política colonial.

Em Maio de 1906 foi publicado um outro artigo sobre a colónia de São Tomé, cujo objectivo era explicado da seguinte forma: 
Com a publicação que o Século fez de todos os documentos relativos ao celebre folheto Alma Negra ficaram bem demonstrados a origem e fins da campanha de descredito que no estrangeiro tem sido feita contra Portugal, no respeitante à mão de obra em S. Tomé. Toda essa campanha não é mais do que uma luta mesquinha de interesses comerciais, hipocritamente mascarada de uma filantropia que, para qualquer dos seus paladinos, está bem longe de ser sincera. A publicação da presente página obedece, como as demais que já temos feito, a um fim patriótico de propaganda e valorização. (6 Maio 1913, 5)

O artigo caracterizava a colónia de São Tomé e sublinhava a importância da produção de cacau, aliada à necessidade de mão-de-obra, para a economia e a sobrevivência das ilhas. Relatava também outras necessidades da colónia, como a construção de mais troços de caminhos-de-ferro, a melhoria da higiene nas localidades maiores e a necessidade de construção de outras obras públicas.

Ao longo do artigo, mencionava-se a campanha britânica. Numa entrevista a um antigo Curador em São Tomé, Arnaldo Vidal, O Século reforçava a importância da mão-de-obra. Vidal apontava para a dificuldade de conciliação entre o capital e o trabalho, mas afirmava que uma inspecção cuidadosa, sobretudo no respeitante à repatriação, resolveria facilmente o problema. Quanto aos chocolateiros, Vidal relatava a sua experiência aquando da visita de Cadbury, o qual teria parecido satisfeito com a atenção de que fora alvo. A razão pela qual Vidal não acrescentava muito acerca dos chocolateiros devia-se ao facto de "a sua campanha de descrédito estar virtualmente morta, depois das medidas tomadas e informações prestadas pelo nosso governo." (6 Maio 1913, 5)

A campanha britânica provocou um conflito aceso na imprensa lusa, atingindo o pico no ano de 1908, quando O Século reportou o que os jornais ingleses publicavam acerca do trabalho indígena nas colónias portuguesas, ao mesmo tempo que refutava as constantes acusações. Em 1913, a campanha reacendeu-se com a publicação de Alma Negra, voltando a focar-se na questão dos serviçais e na figura de William Cadbury. A propaganda de O Século não pretendia ser em defesa das condições de vida dos serviçais em São Tomé, mas sim contra os britânicos, numa acção de contra-propaganda. 
Deste modo, pode afirmar-se que os anos da campanha, que durou mais de uma década, representaram um momento de extrema anglofobia na imprensa lusa. Todavia, a propaganda jornalística, na tentativa de atrair seguidores, reflectia a natureza dúbia das notícias oriundas de ambos os lados. Uma eventual análise (mais aturada) da imprensa britânica coeva complementaria decerto o presente artigo da perspectiva dos Estudos Anglo-Portugueses. Embora a campanha tivesse terminado em 1916, o boicote levado a cabo pelos chocolateiros britânicos nunca foi levantado, apesar das melhorias visíveis quanto ao sistema de repatriação. As verdadeiras razões por detrás da campanha também não foram totalmente desvendadas, embora as suspeitas do jornal $O$ Século recaíssem na mudança de estratégia económica britânica.

\section{Conclusões}

A questão da campanha dos Cadbury, que se desenrolou ao longo das primeiras décadas do século XX e que levou ao boicote da importação de cacau de São Tomé, foi bastante ambígua, levantando muitas questões relativas à sua própria natureza.

Do lado português levantou-se o problema da verdadeira existência de escravatura em Angola e nas ilhas de São Tomé e Príncipe. A fraca administração portuguesa no interior de Angola leva a crer que existia, de facto, comércio de escravos com destino a São Tomé. As condições de vida dos serviçais nas ilhas eram melhores do que em Angola, mas o problema da repatriação era bastante visível e os relatórios dos britânicos não deixavam margem para dúvidas. Todavia, a existência de diversos relatórios com conteúdos muito questionáveis colocava em dúvida a sua veracidade. Deve ter-se também em consideração que as condições de trabalho eram diferentes em cada roça. Contudo, de uma forma geral, pode confirmar-se a existência de trabalho escravo numa colónia que tentava melhorar as condições de vida dos serviçais. 
Pode também questionar-se as razões pelas quais o Governo português não impediu o recrutamento de indígenas em Moçambique para as minas do Transval, como resposta à campanha britânica. De facto, a campanha não era bem vista pelo Foreign Office, que tentava, junto do Governo português, estabelecer um acordo para resolver o problema da falta de mão-de-obra no Transval. Tal leva a concluir que a campanha causou alguma tensão interna na Grã-Bretanha, decorrente do desequilíbrio de interesses por parte dos britânicos. Essa tensão terá constituído a causa principal do seu prolongamento. Se, num primeiro momento, os britânicos atacavam Portugal quanto às condições de trabalho nas colónias, em seguida focavam-se, antes, na forma de recrutamento dos serviçais.

O boicote ao cacau de São Tomé foi realizado em nome de uma causa humanitária dirigida pelos Quaker. No entanto, a imprensa portuguesa acusou sobretudo os chocolateiros de usarem esse pretexto como um véu para cobrir outras razões, estratégia que O Século denominou campanha disfarçada. As constantes acusações feitas aos britânicos por O Século evidenciavam o sentimento de anglofobia que grassava em Portugal. Para além de causar tensão entre as duas nações, a campanha constituiu mais um problema para a Aliança luso-britânica, que passara há pouco por um período negro com as consequências do Ultimatum de 1890, e que voltaria a ser questionada aquando da implantação da República. 


\section{Obras Citadas I) Fontes Primárias}

Anónimo. "Alma Negra'”. O Século (26 Abril 1913): 1.

---. "A 'Escravatura' Portugueza". O Século (14 Outubro 1908): 4.

---. "A Campanha contra Portugal". O Século (11 Março 1907): 5.

---. "A Campanha dos Chocolateiros e o seu Aspeto Politico". O Século (25 Abril 1913): 1 .

---. "A Questão dos Serviçaes e a Campanha Ingleza". O Século (30 Setembro 1908): 1.

---. "A Questão dos Serviçaes e a Campanha Ingleza". O Século (1 Outubro 1908): 1.

---. "A Questão dos Serviçaes nas Colonias Portuguesas". O Século (11 Março 1907): 6.

--.. "A Questão dos Serviços nas Colonias." O Século (5 Dezembro 1906): 2.

---. "Campanhas contra Portugal". O Século (6 Abril 1913): 1.

---. "Campanhas contra Portugal". O Século (7 Abril 1913): 1.

---. "Campanhas Odiosas contra Portugal". O Século (5 Abril 1913): 1.

---. "Ilha de S. Thomé". O Século (2 Março 1907): 2.

---. “O Relatório do sr. Burtt é publicado em Londres”. O Século (11 Outubro 1908): 1.

---. "Os Serviçaes de S. Thomé: A Propaganda de Descredito combatida pelo "Tour du Monde'". O Século (1 Fevereiro 1907): 2.

---. "Paiva de Carvalho repudía a Paternidade do seu Folheto 'Alma Negra'". O Século (9 Abril 1913): 1.

---. "S. Tomé". O Século (6 Maio 1913): 5.

---. "Uma Carta de Nevinson publicada no 'Standard'". O Século (8 Outubro 1908): 1.

Carvalho, Jerónimo de. “Desfazendo as Calumnias". O Século (8 Outubro 1908): 2.

\section{II) Fontes Secundárias}

Almada, José de. Apontamentos Históricos sôbre a Escravatura e o Trabalho Indígena nas Colónias Portuguesas. Lisboa: Imprensa Nacional, 1932.

---. Comparative Essay on Indentured Labour at St. Thomé and Principe. Lisboa: Imprensa Nacional, 1913. 
Beller, Manfred e Joep Leersseen (eds.) Imagology. The Cultural Construction and Literary Representation of National Characters. A Critical Survey. Amsterdam/ New York: Rodopi, 2007, vol. 13 of the Studia Imagologica.

Cadbury, Deborah. Chocolate Wars. The 150-Year Rivalry between the World's Greatest Chocolate Makers. New York: Public Affairs, 2010.

Cadbury, William. Os Serviçaes de S. Thomé: Relatório d'uma Visita às Ilhas de S. Thomé e Principe e a Angola, feita em 1908, para Observar as Condições da Mão d'Obra Empregada nas Roças de Cacau da África Portugueza. Trad. Alfredo H. da Silva. Lisboa: Bertrand, 1910.

Chorão, Luís Bigotte. "Escravatura? What Slavery?". Política e Justiça na I República, 1910-1915. Lisboa: Letra Livre, 2011. 285-292.

Dandelion, Pink. The Quakers: A Very Short Introduction. Oxford: Oxford University Press, 2008.

Duffy, James. A Question of Slavery. Oxford: The Clarendon Press, 1967.

---. Portugal in Africa. Middlesex: Penguin Books, 1962.

Hammond, R. J.. Portugal and Africa 1815-1910: a Study in Uneconomic Imperialism. Stanford: Stanford University Press, 1966.

Machado, Álvaro Manuel, e Daniel-Henri Pageaux. Da Literatura Comparada à Teoria da Literatura. $2^{\text {a }}$ edição revista e aumentada. Lisboa: Edições 70, 2001.

Melo, Lopo Vaz de Sampaio e. Política Indígena: Questões Coloniais. Porto: Magalhães \& Moniz, 1910.

Nevinson, Henry e Basil Davidson. A Modern Slavery. London: William Clowes and Sons, 1963.

Nworah, Kenneth D.. "The Aborigines' Protection Society, 1889-1909: A Pressure-Group in Colonial Policy". Canadian Journal of African Studies / Revue Canadienne des Études Africaines, Vol. 5, No. 1 (1971): 79-91.

Santos, Maciel Morais. “Um Episódio do 'Slave Cocoá' - o Relatório Nightingale de 1906". Estudos em Homenagem a Luís António de Oliveira Ramos. Porto: Faculdade de Letras da Universidade do Porto, 2004. 965-983.

Wollaeger, Mark. Modernism, Media, and Propaganda. British Narrative From 1900 to 1945. Princeton/Oxford: Princeton University Press, 2008.

Walton, Douglas. Media Argumentation: Dialectic, Persuasion and Rhetoric. Cambridge: Cambridge University Press, 2007. 
REAP / JAPS 27

\section{Anexos}

Anexo $1^{16}$

\begin{tabular}{l|l|c|c|c}
\multicolumn{2}{c}{} & $\begin{array}{c}\text { From } \\
\text { Angola }\end{array}$ & $\begin{array}{c}\text { From } \\
\text { Moçambique }\end{array}$ & $\begin{array}{c}\text { From } \\
\text { Cape Verdes }\end{array}$ \\
\hline \multirow{2}{*}{1916} & To São Tomé & 3573 & 5439 & 86 \\
\cline { 2 - 5 } & To Príncipe & 660 & -- & 677 \\
\hline \multirow{2}{*}{1917} & To São Tomé & 1918 & 3499 & 47 \\
\cline { 2 - 5 } & To Príncipe & 465 & 148 & 279 \\
\hline \multirow{2}{*}{1918} & To São Tomé & 937 & 570 & 40 \\
\cline { 2 - 5 } & To Príncipe & 779 & 192 & 68 \\
\hline \multirow{2}{*}{1919} & To São Tomé & 5399 & 68 & 190 \\
\cline { 2 - 5 } & To Príncipe & 985 & 18 & 121 \\
\hline
\end{tabular}

16. Estatísticas apresentadas em Duffy, A Question of Slavery, 228-229. 
ESTUDOS / ESSAYS

\begin{tabular}{|c|c|c|c|c|}
\hline \multicolumn{5}{|c|}{ Repatriated } \\
\hline & & $\begin{array}{c}\text { To } \\
\text { Angola }\end{array}$ & $\begin{array}{c}\text { To } \\
\text { Moçambique }\end{array}$ & $\begin{array}{c}\text { To } \\
\text { Cape Verdes }\end{array}$ \\
\hline \multirow{2}{*}{1916} & $\begin{array}{l}\text { From } \\
\text { São Tomé }\end{array}$ & 2949 & 2433 & 44 \\
\hline & $\begin{array}{l}\text { From } \\
\text { Príncipe }\end{array}$ & 186 & 14 & 802 \\
\hline \multirow{2}{*}{1917} & $\begin{array}{l}\text { From } \\
\text { São Tomé }\end{array}$ & 2553 & 420 & 30 \\
\hline & $\begin{array}{l}\text { From } \\
\text { Príncipe }\end{array}$ & 118 & 12 & 305 \\
\hline \multirow{2}{*}{1918} & $\begin{array}{l}\text { From } \\
\text { São Tomé }\end{array}$ & 1484 & 1404 & 15 \\
\hline & $\begin{array}{l}\text { From } \\
\text { Príncipe }\end{array}$ & 82 & 2 & 472 \\
\hline \multirow{2}{*}{1919} & $\begin{array}{l}\text { From } \\
\text { São Tomé }\end{array}$ & 1333 & 1248 & 71 \\
\hline & $\begin{array}{l}\text { From } \\
\text { Príncipe }\end{array}$ & 420 & 63 & 468 \\
\hline \multirow{2}{*}{1920} & $\begin{array}{l}\text { From } \\
\text { São Tomé }\end{array}$ & 1826 & 1044 & 39 \\
\hline & $\begin{array}{l}\text { From } \\
\text { Príncipe }\end{array}$ & 136 & 1 & 115 \\
\hline
\end{tabular}


REAP / JAPS 27

\begin{tabular}{c|l|c|c|c}
\multicolumn{2}{c}{} & $\begin{array}{c}\text { Recontracted } \\
\text { Angola }\end{array}$ & $\begin{array}{c}\text { From } \\
\text { Moçambique }\end{array}$ & $\begin{array}{c}\text { From } \\
\text { Cape Verdes }\end{array}$ \\
\hline \multirow{2}{*}{1916} & On São Tomé & 1775 & 1661 & 4 \\
\cline { 2 - 5 } & On Príncipe & 22 & 7 & 186 \\
\hline \multirow{3}{*}{1917} & On São Tomé & 2706 & 6065 & 19 \\
\cline { 2 - 5 } & On Príncipe & 112 & 29 & 324 \\
\hline \multirow{3}{*}{1918} & On São Tomé & 1566 & 6970 & 25 \\
\cline { 2 - 5 } & On Príncipe & 142 & 60 & 23 \\
\hline \multirow{2}{*}{1919} & On São Tomé & 3550 & 7451 & 534 \\
\cline { 2 - 5 } & On Príncipe & 133 & 62 & 14 \\
\hline & On São Tomé & 1050 & 3021 & 209 \\
\cline { 2 - 5 } & On Príncipe & 51 & 61 & 23 \\
\hline
\end{tabular}

